\title{
The role of university on economic development in heritage tourism area in Malang City, Indonesia
}

\author{
V.A. Qurrata*, S. Merlinda, V. Purnamasari \\ Universitas Negeri Malang, Malang, Indonesia
}

\begin{abstract}
Community service activities in revitalizing religious tourism were carried out to increase tourist numbers, mostly visits by young generations, expanding the community's economy and introducing history to visitors. Malang City's relatively high tourism potential must be the point of attention of all social elements. University is expected to be a role model in analyzing solutions to problems to create a prosperous and independent society through tourism. Activities were carried out using the focus group discussion method to socialize and prepare for development. We then assisted in developing and implementing training and evaluation of performance. The service contributed to iconic photo spots and parks around Mbah Honggo's grave, direct marketing strengthening movement through Mbah Honggo's historical posters, and social media training (Google My Business). The evaluation results provide concluded that the number of tourist visits is increased so that the surrounding community's economy is also developed. This also served as additional historical knowledge for visitors.
\end{abstract}

Keywords: economics development; Kampoeng heritage; tourism area; religious tourism

\section{INTRODUCTION}

Malang City is one of the tourist areas in East Java, Indonesia, visited for tourism. According to data from the Malang City Tourism Outlook (2019), the tourism sector contributes 25.56 percent of PAD to Malang City. The number of tourists in 2019 amounted to 5.170 .523 and foreign tourists of 16.286 (BPS 2019). It is an opportunity and a challenge to make maximum use of the tourism potential in Malang, especially in the heritage tourism area in the era of digitalization. The development of the internet is one of the new tools in capturing and expanding potential customers, specifically aimed at millennials tourism. Thus, tourism development is directed to be a mainstay sector capable of helping or competing activities in the economic sector and other related industries (Sutiarso 2017). Community service activities in the form of revitalizing religious tourism are carried out to increase tourists' numbers, mostly visits by young generations, expanding the community's economy and introducing history to visitors.

This activity is intended for managers and the religious tourism community of Mbah Honggo, who are precisely located at Kampoeng Heritage Kajoetangan as many as ten people. In its development, the religious tourism community of Mbah Honggo faces problems due to the inadequate facilities available. It is a crucial problem because, in the era of millennials tourism, attractive facilities are used as capital to absorb potential consumers as a positive impact of the internet in the tourism sector, namely low promotional costs (Rusdi 2019) and the uneven information regarding the existence of religious tourism in Kampoeng Heritage.

Therefore, to solve partner problems, the university provides an analysis of issues and solutions to partners in Kampoeng Heritage Kajoetangan. The activities were carried out using Focus Group

*Corresponding author: vika.annisa.fe@um.ac.id 
Discussion to socialize and prepare for development, and we also assisted in the implementation of development and implementation training and evaluation of performance. The service contributed to iconic photo spots and parks around Mbah Honggo's grave, direct marketing strengthening movement through Mbah Honggo's historical posters, and social media training through Google My Business. Based on the evaluation and monitoring of this activity, it concluded that the number of tourist visits is increased so that the surrounding community's economy is also developed and adds as historical knowledge for visitors.

\section{METHODS}

In developing Mbah Honggo, religious tourism was carried out in three strategic steps. The first is the Focus Group Discussion method to socialize and prepare for development. The FGD model was carried out to identify the problems and the size of the tourism potential (Pratama 2019). In this case, the FDG included a tourism community, representatives of local and regional leaders, and community service programs. Second, we assisted in the implementation of development and implement training. The program was installing a letter sign and improving the marketing strategy for the Mbah Honggo Tomb Area. It was carried out with the following stages and methods: preparing an activity plan and collecting data using primary data and secondary data through field observations. Moreover, exploring the site, documentation, and interviews were also done. Literature study on the concept of suitable letter sign design and marketing strategies is required to attract tourists, especially the younger generation, to visit there, qualitative descriptive data analysis, and installation of letter signs and online marketing training for tourism area managers. Finally, evaluation of the implementation was done.

\section{RESULTS AND DISCUSSION}

As a part of cultural tourism, heritage tourism has a significant attraction that proliferates (Franch et al. 2017). The existence of heritage tourism can increase opportunities and interactions between residents and visitors to increase income (Nicholas \& Thapa 2010). Therefore, the citizen's role in the development of heritage tourism is crucial in its progress and development. One of the population's roles in developing tourist areas is services, such as communication skills in foreign languages, and tourism maintenance services such as maintaining advice and infrastructure (Zhang \& Stewart 2017). Resources in tourism include an environmental component, either physical or social, which provides the infrastructure to attract tourist visits (Bucurescu 2012; Cooper \& Hall 2008; Darabseh et al. 2017). The results and discussion of community service programs in the form of focus group discussions and assistance in the form of facilities at Mbah Honggo Religious Tourism and training for the community were divided into three stages. The SWOT analysis of the Mbah Honggo religious tourism area is shown in Figure 1.

SWOT analysis presented in the Figure above shows the real condition of Kampoeng Heritage Kajoetangan. Based on the explanation, several weaknesses exist in the place's internal management, and most of them are caused by the lack of facilities. While facing the internal weakness, the management also faces other external challenges such as Kampoeng Heritage Kajoetangan is threatened by other tourism places in Malang. The most significant issue in this problem includes limited promotion held by the management.

On the other hand, there is a massive strength that the Kampoeng Heritage Kajoetangan has, such as strategic location and sentimental object, which can attract tourists. Opportunities will empower and support the local communities' strength if they put a significant effort to develop this area. From the SWOT analysis data, a strategy that can be taken from the partners' problems can be represented in Figure 2.

The SWOT analysis be conducted based on the community's internal activities while adjusting with the external fact that happened in real life. Using the SWOT analysis internally, we can 


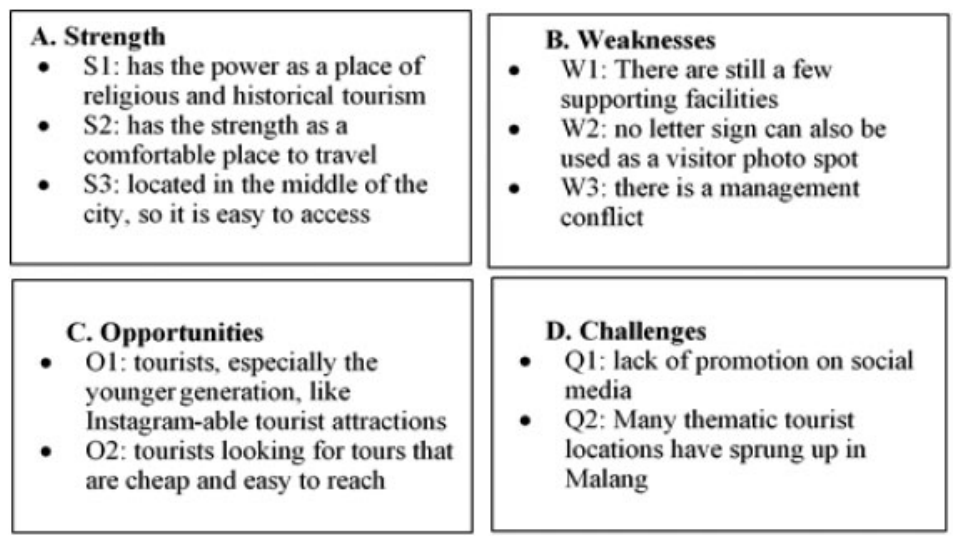

Figure 1. SWOT analysis of the Mbah Honggo religious tourism area.

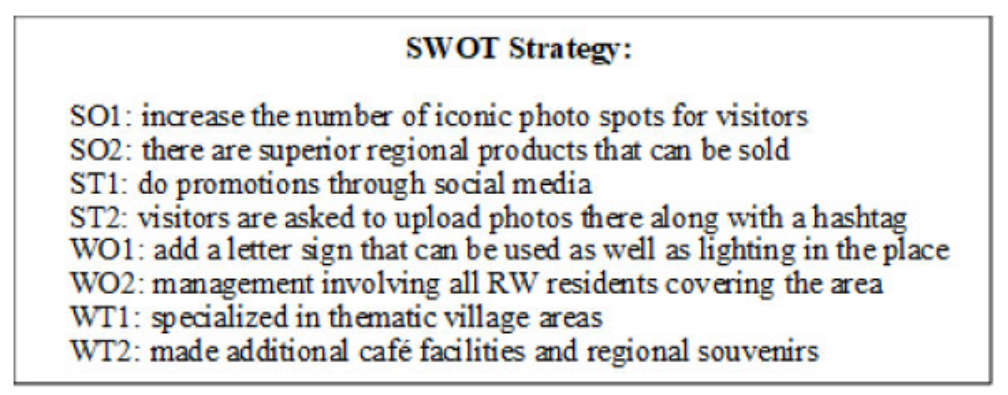

Figure 2. SWOT strategy of the Mbah Honggo religious tourism area.

maximize the strength and minimize the weaknesses. Externally, we could exploit the challenges and opportunities available to support a better vision in the future. Using the SWOT Strategy above, we focus on several activities that combine activities using strength to challenge the opportunities, use strength to minimize the threat, minimize the weakness by using the opportunities, and minimize the weaknesses based on the threat in reality.

This analysis decides to improve facilities and strengthen marketing strategies through social media. This decision is also assessed based on the essential needs, according to managers and the community. With an attractive photo spot, the hope is that tourist visits will increase (Kuenzi 2008). The coordination process with the local area head, community group, and the site management resulted in planning activities, including budget planning and costs adjusted to the RAB. The coordination results concluded that this tourism revitalization's priority needs were the construction of iconic photo spots accompanied by lighting (neon boxes), strengthening direct marketing through foreign languages in serving tourists, and strengthening promotions through Google My Business.

In this program, residents would assist in the construction of iconic photos and strengthen direct marketing carried out by the team. One of the things that were done by the group was to find, collect, and summarize Mbah Honggo's historical data. The summary is also discussed and validated by the local community watch, which will then be displayed in the historical tourism area. Furthermore, the community service team's revitalization process is monitored by the regional area head. After handing over the aid, the community groups, then the community, made improvements to tourism facilities, namely making iconic photos that also serve as lighting for the area. Then, our team also assists in improving tourism support facilities, as stated in the following figure. 
VISITORS

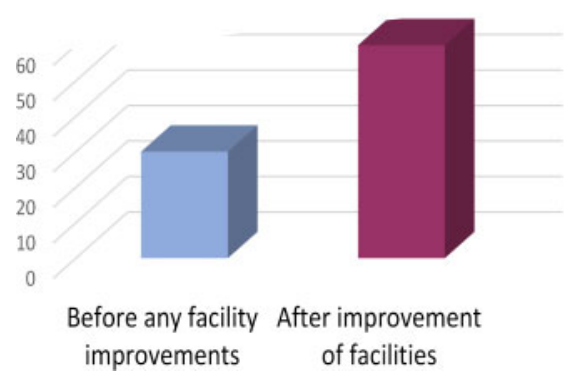

Retribution Per Day

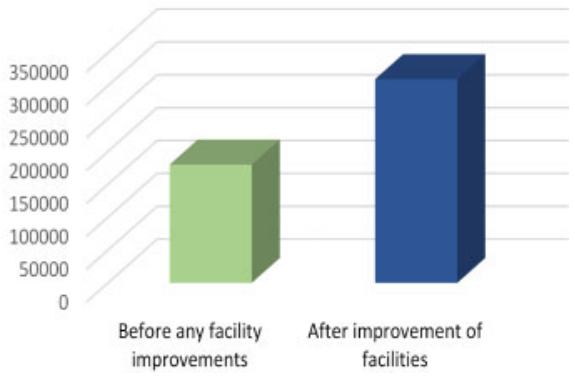

Figure 3. Visitors (left side) and retribution per day (right side).

Furthermore, the development of iconic photo spot development was in the development process. After the revitalization was carried out, especially on iconic photos, another thing that was also done was direct marketing education. Education direct marketing is implemented in English strengthening for all residents, including community watch and women's groups, to facilitate marketing and improve the performance of more excellent tourism services. Moreover, a form of direct marketing education is the inclusion of Mbah Honggo's history in the form of posters, which are packaged in two languages, namely Indonesian and English. It is due to the convenience of guides in explaining and foreign tourists in understanding the history and origin of Mbah Honggo.

After the design of Mbah Honggo's History pamphlet was compiled, it was printed and handed over to the community watch group and the local head area, witnessed by the local community and representatives of the Malang City Tourism Office. The final implementation of this activity is social media promotion training. The presence of social media nowadays has become a significant need (Fandeli 2001). All age groups have used social media for communication needs and business needs (Wolah 2016). The media used was the creation of Google My Business. Google My Business is a platform from Google, where business owners can provide detailed business information. When someone searches on a search engine, the search results will appear complete with a map of directions, making it easier for potential customers to find Google locations. Besides, through this feature, it will be easier for business owners to create and update listings so that their business will stand out more. For entrepreneurs and businesspeople, Google My Business is very useful for promoting a business, and from the satisfactory promotional results, business managers can increase the company's sales. The detail of visitor numbers and retribution numbers per day can be seen in Figure 3.

The development of Mbah Honggo religion tourism shows positive growth, an increase in tourist visits from before and after the facility's construction. It also provides a multiplier effect of an increase in the number of fees. These results align with research in developing a tourist village in Tulungrejo Village by Amalia et al. (2018). This research shows new economic activities that open jobs and additional income for the surrounding community. This effect also affects farmers in increasing the selling value of apples and research conducted by Wijayanti (2017), in descriptive survey research that analyzes the impact of developing the tourism village of Kembangarum on the community's economy.

\section{CONCLUSION}

Opportunities and challenges to exploit the tourism potential in Malang City, especially in the heritage tourism area in a digital age, are very crucial and require the right strategy. In resolving partner problems, namely supporting facilities for heritage tourism villages, we are revitalizing historical tourism by creating iconic photo spots. The landmarks were built as iconic photo spots that function as grave markers and visitors' sites to capture moments in the Religious Tourism area 
of Mbah Honggo's Tomb. In addition to physical revitalization, we also conduct search engine marketing training to facilitate promotion strengthening and market capture. Then, the strengthening of direct marketing was carried out to support all languages of the citizens, including community watch and women's groups, to provide full services to domestic tourists and foreign tourists. This program can increase the role of universities in increasing the competitiveness of tourist areas. The revitalization of heritage tourism has risen to visitors of up to 100 percent, accompanied by an increase in fees. Thus, the income of the surrounding community can rise through the opening of new jobs.

\section{REFERENCES}

Amalia VGA, N., Kusumawati, A., \& Hakim, L. 2018. Partisipasi Masyarakat dalam Pengembangan Desa Wisata serta Dampaknya terhadap Perekonomian Warga di Desa Tulungrejo Kota Batu. Jurnal Administrasi Bisnis, 61(3), 48-56.

BPS. 2019. Statistik Kunjungan Wisatawan Mancanegara. Accessed on November 24 at 13.39 WIB. Available at: https://malangkota.bps.go.id/subject/16/pariwisata.html\#subjekViewTab1

Bucurescu, L. 2012. Assessment of tourism potential in historic towns: Romanian case studies. In International conference: The role of tourism the territorial development (conf. Proceeding). Press Universitatea Clugeana, Gheiorgheni.

Cooper, C., Hall, M. 2008. Contemporary tourism: an international approach. Butterworth-Heinman London.

Darabseh, F.M., Ababneh, A. \& Almuhaisen, F. 2017. Assessing Umm el-Jimal's Potential for Heritage Tourism. Arch 13, 460-488. https://doi.org/10.1007/s11759-017-9327-5

Faizal, E., Suprawoto, T., Kurniyati, N. N., \& Setyowati, S. (2020). Pengembangan Wisata Tematik Sebagai Rintisan Kawasan Edukatif Ramah Anak. Jurnal Berdaya Mandiri, 2(1), 202-214.

Fandeli, C. 2001. Dasar-Dasar Manajemen Kepariwisataan Alam. Yogyakarta.

Franch, M., Irimiás, A. \& Buffa, F. 2017. Place identity and war heritage: managerial challenges in tourism development in Trentino and Alto Adige/Südtirol. Place Brand Public Dipl 13, 119-135. https://doi.org/10.1057/s41254-016-0019-5

Komariah, N., Saepudin, E., \& Yusup, P. M. 2018. Pengembangan Desa Wisata Berbasis Kearifan Lokal. Jurnal Pariwisata Pesona, 3(2). https://doi.org/10.26905/jpp.v3i2.2340

M. J. Kuenzi C., 2008. Nature-Based Tourism. In: Renn O., Walker K.D. (eds) Global Risk Governance. International Risk Governance Council Bookseries. Dordrecht: Springer.

Nicholas, L., Thapa, B. 2010. Visitor perspectives on sustainable tourism development in the Pitons Management Area World Heritage Site, St. Lucia. Environ Dev Sustain 12, 839-857. https://doi.org/ 10.1007/s10668-009-9227-y

Pitana, I Gde, Gayatri, dan Putu G. 2005. Sosiologi Pariwisata. Yogyakarta: Andi Offset.

Rusdi, J. F. 2019. Peran Teknologi pada Pariwisata Indonesia. Jurnal Accounting Information System (AIMS). https://doi.org/10.32627/aims.v2i2.78

Setiadi, Amos., L.A. Rudwiarti. 2020. Penataan Kawasan Wisata Curug Banyu Nibo Desa Sendangsari Kecamatan Pajangan Kabupaten Bantul Daerah Istimewa Yogyakarta. Jurnal PATRIA (media online) Vol. 2(1).

Sutiarso, M. A. 2017. Pengembangan Pariwisata Yang Berkelanjutan Melalui Ekowisata. Manajemen Kepariwisataan Di Sekolah Tinggi Pariwisata Bali Internasional (STPBI).

T. D. Oonowska M. 2016. Toward a sustainable tourism. In Tourism Management, Marketing, and Development. In: Mariani M.M., Czakon W., Buhalis D., Vitouladiti

Wijayanti, A. 2017. Analisis Dampak Pengembangan Desa Wisata Kembang Arum Terhadap Perekonomian Masyarakat Lokal. Sarjana Wiyata Tamansiswa Yogyakarta.

Wiyatiningsih. 2015. Global-Lokal: Kreativitas Meruang Sebagai Strategi Keberlanjutan Desa Wisata Puton Bantul. Konferensi Nasional II Forum Wahana Teknologi Yogyakarta, Yogjakarta, 10 Agustus 2015.

Wolah, Ferni Fera Ch. 2016. Peranan Promosi dalam Meningkatkan Kunjungan Wisatawan di Kabupaten Poso. Acta Diurna. 5(2), 23-40.

Yuniwati, E. D., Darmawan, A. A., \& Firdaus, R. 2020. Eksplorasi Potensi Alami Waduk Menuju Rancangan Wisata Desa Purwosekar Tajinan Kabupaten Malang. Dinamisia: Jurnal Pengabdian Kepada Masyarakat, 4(3), 398-407.

Zhang, L., Stewart, W. 2017. Sustainable Tourism Development of Landscape Heritage in a Rural Community: A Case Study of Azheke Village at China Hani Rice Terraces. Built Heritage 1, 37-51. https://doi.org/10.1186/BF03545656. 